\title{
ANALISIS PEMAHAMAN KONSEP MATEMATIKA SISWA DALAM MENYELESAIKAN SOAL FAKTORISASI SUKU ALJABAR BERDASARKAN KESULITAN BELAJAR FAKTOR INTELEKTUAL SISWA PADA KELAS VIII B SMP N 8 SURAKARTA TAHUN AJARAN 2016/2017
}

\author{
Novita Ayu Dewanti' ${ }^{1)}$, Ponco Sujatmiko' ${ }^{2)}$, Getut Pramesti ${ }^{3)}$ \\ ${ }^{1)}$ Mahasiswa Pendidikan Matematika, Program Pasca Sarjana, UNY, Yogyakarta \\ ${ }^{2), 3)}$ Dosen Prodi Pendidikan Matematika, FKIP, UNS, Surakarta
}

\begin{abstract}
This study aims to describe the understanding of students' mathematical concepts in solving the factorization of algebraic tribes. The method used is descriptive qualitative. The subjects of the study were 6 students of class VIII B Surakarta State Junior High School 8 divided into 3 groups, namely the group of low, medium and high learning difficulties. Data collection techniques include tests and interviews. The results showed that (1) students who had low learning difficulties were able to master most of the indicators that were determined, only one indicator that had not been mastered, namely determining variables. (2) Students who have moderate learning difficulties have been able to master most of the indicators set, but there are indicators that have not been mastered, namely determining variables and there are several indicators that have not been smoothly mastered. (3) Students who have high learning difficulties have been able to master to determine examples of algebraic problems and students have not been able to master the indicators stating an operation, completing various algebraic forms, operating and using them.
\end{abstract}

Key words: concept understanding, learning difficulties, intellectual factors, analysis

\begin{abstract}
Abstrak
Penelitian ini bertujuan untuk mendeskripsikan pemahaman konsep matematika siswa dalam menyelesaikan soal faktorisasi suku aljabar. Metode yang digunakan adalah deskriptif kualitatif. Subjek penelitian yaitu 6 orang siswa kelas VIII B SMP Negeri 8 Surakarta yang terbagi 3 kelompok, yaitu kelompok kesulitan belajar rendah, sedang, dan tinggi. Teknik pengumpulan data yaitu tes dan wawancara. Hasil penelitian menunjukkan bahwa (1) siswa yang memiliki kesulitan belajar rendah telah mampu menguasi sebagian besar indikator yang ditetapkan, hanya satu indikator yang belum dikuasai yaitu menentukan variabel. (2) Siswa yang memiliki kesulitan belajar sedang telah mampu menguasi sebagian besar indikator yang ditetapkan, namun terdapat indikator yang belum dikuasai yaitu menentukan variabel dan ada beberapa indikator yang belum lancar dikuasai. (3) Siswa yang memiliki kesulitan belajar tinggi telah mampu menguasai hingga menentukan contoh soal bentuk aljabar dan siswa belum mampu menguasai indikator menyatakan suatu operasi, menyelesaikan berbagai bentuk aljabar, mengoperasikan serta penggunaannya.
\end{abstract}

Kata kunci: pemahaman konsep, kesulitan belajar, faktor intelektual, analisis 
Novita Ayu Dewanti, Ponco Sujatmiko, Getut Pramesti/ Phenomenon Vol. 08, No. 1, Juli 2018 PENDAHULUAN

SMP N 8 Surakarta merupakan salah satu SMP yang berada di Surakarta, Jawa Tengah. Pada tingkat SMP, Aljabar merupakan salah satu kajian inti yang perlu dipahami. Jika dilihat dari nilai ulangan harian bab faktorisasi suku aljabar, siswa SMP N 8 Surakarta masih memperoleh nilai yang kurang memuaskan. Berdasarkan hasil wawancara dengan guru matematika kelas VIII SMP N 8 Surakarta pada tanggal 25 Oktober 2016, diperoleh informasi bahwa siswa kelas VIII SMP N 8 Surakarta masih mengalami kesulitan belajar. Hal ini dapat dilihat dari hasil nilai ulangan harian siswa pada bab faktorisasi suku aljabar, banyak siswa yang belum memenuhi Kriteria Ketuntasan Minimal (KKM). Berdasarkan observasi yang dilakukan peneliti di SMP N 8 Surakarta, masih sedikit siswa yang telah mencapai nilai KKM (tuntas) pada ulangan harian bab faktorisasi suku aljabar yaitu sebesar 75. Hal ini dapat dilihat dari tabel ketuntasan hasil ulangan harian siswa pada Tabel 1.1.

Table 1.1 Ketuntasan Hasil Ulangan Harian Siswa SMP N 8 Surakarta

\begin{tabular}{ccc}
\hline Kelas & Jumlah siswa & Ketuntasan \\
\hline VIII A & 32 & $46.8 \%$ \\
VIII B & 24 & $20.8 \%$ \\
VIII C & 32 & $37.5 \%$ \\
VIII D & 26 & $42.3 \%$ \\
VIII E & 26 & $15.4 \%$ \\
\hline
\end{tabular}

Berdasarkan tabel diatas dapat diinformasikan bahwa ketuntasan siswa paling tinggi adalah 46.8\%. Hal ini menunjukkan bahwa lebih dari setengah siswa pada tiap kelas belum mencapai nilai KKM. Menurut Dalyono (1997), cara mengenali siswa yang mengalami kesulitan belajar adalah dengan mengamati gejala gejala yang bisa diamati oleh orang lain (guru, pembimbing), salah satunya adalah menunjukkan prestasi yang rendah atau di bawah rata-rata yang dicapai oleh kelompok kelas. Menurut Abdurrahman (2010), umumnya guru memandang semua siswa yang memperoleh prestasi belajar rendah disebut siswa berkesulitan belajar. Pada kasus ini, banyaknya siswa yang tidak tuntas tiap kelas menunjukkan pretasi yang rendah. Hal ini mengisyaratkan bahwa siswa mengalami kesulitan dalam memahami materi faktorisasi suku aljabar. Menurut Cooney, Davis, dan Hendersen dalam (Widdiharto, R., 2008), kesulitan belajar siswa dapat bersumber dari beberapa faktor, antara lain adalah faktor fisiologis, faktor sosial, faktor emosional, faktor intelektual dan faktor pedagogis. Siswa yang mengalami kesulitan belajar dikarenakan faktor intelektual, umumnya kurang 
Novita Ayu Dewanti, Ponco Sujatmiko, Getut Pramesti/ Phenomenon Vol. 08, No. 1, Juli 2018 berhasil dalam menguasai konsep, prinsip atau algoritma walaupun sudah berusaha mempelajarinya sehingga mengakibatkan prestasi belajarnya tidak maksimal.

Menurut Aini R.N. \& Siswono, T.Y.E. (2014), kemampuan pemahaman matematika siswa sejalan dengan kemampuan dalam menyelesaikan masalah. Berdasarkan hasil wawancara dengan guru matematika kelas VIII SMP N 8 Surakarta pada tanggal 23 Juli 2016, kebanyakan siswa belum mampu menyelesaikan masalah pada sub materi perpangkatan, pemfaktoran dan penyederhanaan pecahan bentuk aljabar. Berdasarkan observasi pada hari sabtu tanggal 23 Juli 2016 di kelas VIII E SMP N 8 Surakarta, siswa belum dapat menyelesaikan masalah dalam menentukan variabel, koefisien, dan banyaknya suku dari suatu persamaan aljabar. Hal ini ditandai dengan pada saat ditunjuk untuk maju, siswa masih terlihat bingung untuk menentukan koefisien yang terdapat dalam persamaan aljabar, siswa masih melakukan kesalahan dalam menjawab soal yang ditanyakan serta dalam menentukan banyak suku. Siswa masih belum paham dengan materi aljabar yang ditandai dengan siswa perlu melihat contoh soal yang sebelumnya. Pada saat itu, suasana kelas kondusif namun cenderung pasif, karena siswa susah dipersilakan maju ke depan kelas untuk mengerjakan soal yang telah dikerjakannya serta ada beberapa siswa yang sibuk sendiri. Ada kemungkinan siswa tersebut mengalami kebingungan dalam memilih jawaban karena siswa kurang memahami konsep aljabar yang telah diterangkan oleh gurunya sehingga tidak dapat menyelesaikan soal yang diberikan. Pemahaman konsep siswa akan berdampak pada hasil belajar siswa, yaitu berupa prestasi belajar sehingga penting bagi guru untuk memperbaiki pemahaman siswa guna untuk meningkatkan kemampuan menyelesaikan masalah.

Berdasarkan rumusan masalah diatas, maka tujuan yang ingin dicapai peneliti adalah mendeskripsikan pemahaman konsep matematika siswa yang memiliki kesulitan belajar rendah, sedang, dan tinggi dalam menyelesaikan soal faktorisasi suku aljabar pada kelas VIII B SMP N 8 Surakarta Tahun Ajaran 2016/2017.

\section{METODE PENELITIAN}

Penelitian ini merupakan penelitian kualitatif dengan menggunakan metode penelitian deskriptif. Sumber data dalam penelitian ini diperoleh dari subjek atau narasumber, yaitu siswa kelas VIII atau guru matematika SMP Negeri 8 Surakarta 
Novita Ayu Dewanti, Ponco Sujatmiko, Getut Pramesti/ Phenomenon Vol. 08, No. 1, Juli 2018 Tahun Ajaran 2016/2017 dimana data yang diperoleh berupa hasil tes, catatan peneliti, dan rekaman saat wawancara berlangsung.

Subjek penelitian ini adalah siswa kelas VIII SMPA N 8 Surakarta Tahun Ajaran 2016/2017. Pemilihan subjek berdasarkan teknik sampel bertujuan (purposive sampling). Penentuan subjek dilakukan dengan melakukan tes kesulitan belajar. Soal tes kesulitan belajar didesain sesuai dengan indikator materi faktorisasi suku aljabar pada kompetensi dasar yang terdapat pada silabus dan indikator kesulitan belajar siswa. Setelah terpilih calon subjek penelitian, kemudian dilakukan wawancara dengan guru matematika untuk menentukan subjek yang digunakan. Penentuan ini berdasarkan pada komunikatif siswa dalam menyampaikan pendapatnya. Subjek penelitian akan dicari kedudukannya dalam kelompok dengan cara menggunakan standar deviasi. Penentuan kedudukan dengan standar deviasi akan dikelompokkan atas 3 kelompok dengan total 6 sampel.

Data penelitian dikumpulkan dengan menggunakan metode tes, wawancara berbasis tugas, observasi dan dokumentasi. Metode tes didesain sesuai dengan indikator materi faktorisasi suku aljabar pada kompetensi dasar yang terdapat pada silabus dan indikator kesulitan belajar siswa serta indikator pemahaman konsep matematika. Metode obeservasi menggunakan observasi partisipasi pasif. Jenis wawancara yang dilakukan dalam penelitian ini merupakan wawancara berbasis tugas. Dokumetasi yang dilakukan dalam penelitian ini berupa mempelajari dokumen yang berupa nama-nama dan juga prestasi akademik yang digunakan sebagai subjek penelitian. Proses analisis data mengikuti model Miles dan Huberman meliputi 3 aktivitas, yaitu reduksi data, penyajian data, dan penarikan kesimpulan/verifikasi (Sugiyono, 2014).

\section{HASIL DAN PEMBAHASAN}

Hasil data dikaji dan dideskripsikan secara kualitatif mengenai pemahaman konsep siswa terhadap materi faktorisasi suku aljabar. Apabila siswa belum dapat menyelesaikan masalah dengan tepat pada masing-masing soal yang telah dihubungkan dengan indikator pemahaman konsep matematika maka siswa dianggap tidak paham pada indikator pemahaman konsep. Pada penelitian ini subjek penelitian terdiri dari 3 kelompok, yaitu kelompok tinggi, siswa dengan inisial ANAQ sebagai subjek k-1 (S1) dan PAS sebagai subjek ke-2 (S2), kelompok sedang, siswa dengan inisial APPT 
Novita Ayu Dewanti, Ponco Sujatmiko, Getut Pramesti/ Phenomenon Vol. 08, No. 1, Juli 2018 sebagai subjek ke-3 (S3) dan MAK sebagai subjek ke-4 (S4), kelompok rendah, siswa dengan inisial ADR sebagai subjek ke-5 (S5) dan siswa dengan inisial FIK sebagai subjek ke-6 (S6).

Adapun hasil dari tes analisis dan wawancara diperoleh data sebagai berikut:

1. Pemahaman konsep matematika siswa yang memiliki kesulitan belajar rendah.

a. Subjek 1

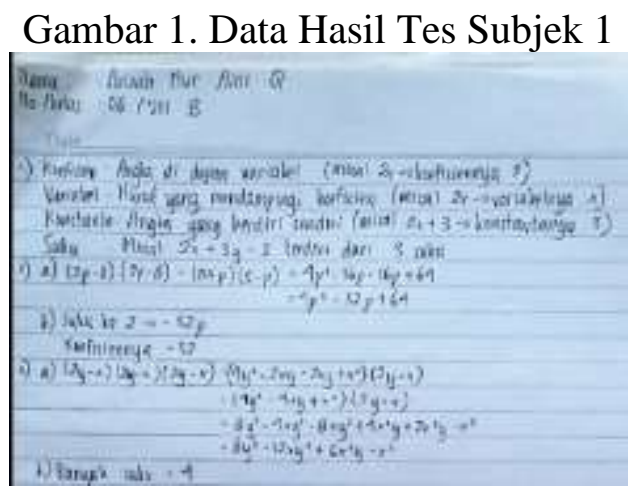

b. Subjek 2

Gambar 2. Data Hasil Tes Subjek 2

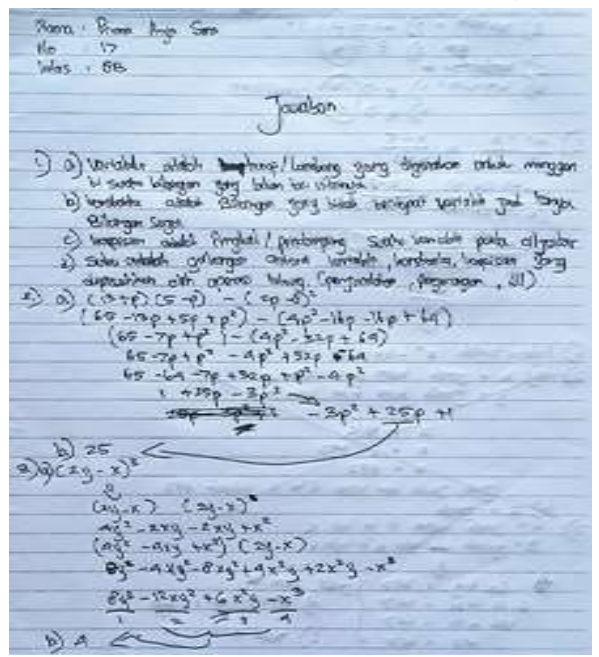

Berdasarkan data yang telah didapat, diperoleh keterangan sebagai berikut : 1) siswa mampu menyatakan ulang sebuah konsep, yaitu telah mampu menyatakan pengertian dari konstanta, variabel, koefisien, dan suku; 2) siswa mampu mengklasifikasi objek menurut sifat-sifat tertentu sesuai dengan konsepnya, yaitu siswa telah mampu dengan lancar menentukan konstanta, koefisien, dan suku dari suatu bentuk aljabar namun belum mampu menentukan variabel dari suatu bentuk aljabar; 3) siswa mampu memberikan contoh dari suatu konsep, yaitu siswa mampu menentukan contoh lain dari permasalahan aljabar; 4) siswa mampu menyajikan konsep dalam berbagai bentuk 
Novita Ayu Dewanti, Ponco Sujatmiko, Getut Pramesti/ Phenomenon Vol. 08, No. 1, Juli 2018 representasi matematis, siswa mampu dengan lancar menyajikan konsep dalam berbagai bentuk representasi matematis; 5) siswa mampu mengembangkan syarat perlu atau syarat cukup dari suatu konsep, yaitu siswa mampu dengan lancar menyelesaikan berbagai bentuk permasalahan aljabar yang melibatkan syarat perlu dan syarat cukup; 6) siswa mampu menggunakan dan memanfaatkan serta memilih prosedur atau operasi tertentu, yaitu siswa mampu dengan lancar mengoperasikan berbagai bentuk permasalahan aljabar dan 7) siswa mampu mengaplikasikan konsep algoritma pada pemecahan masalah, yaitu siswa mampu dengan lancar menggunakan konsep faktorisasi suku aljabar pada pemecahan masalah.

2. Pemahaman konsep matematika siswa yang memiliki kesulitan belajar sedang.

a. Subjek 3

Gambar 3. Data Hasil Tes Subjek 3

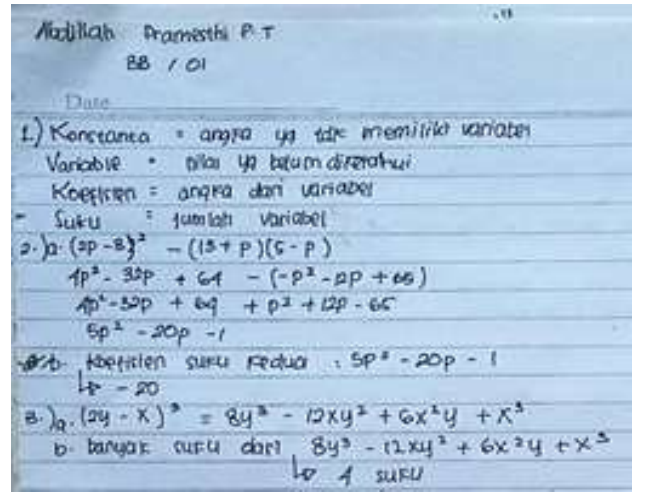

b. Subjek 4

Gambar 4. Data Hasil Tes Subjek 4

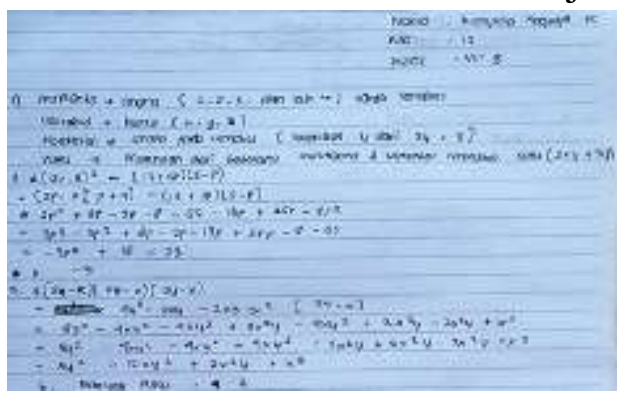

Berdasarkan data yang telah didapat, diperoleh keterangan sebagai berikut : 1) siswa mampu menyatakan ulang sebuah konsep, yaitu telah mampu menyatakan pengertian dari konstanta, variabel dan koefisien namun belum mampu menyatakan ulang konsep suku; 2) siswa mampu mengklasifikasi objek menurut sifat-sifat tertentu sesuai dengan konsepnya, yaitu siswa telah mampu dengan lancar menentukan 
Novita Ayu Dewanti, Ponco Sujatmiko, Getut Pramesti/ Phenomenon Vol. 08, No. 1, Juli 2018 konstanta, koefisien, suku dari suatu bentuk aljabar namun belum mampu menentukan variabel dari suatu bentuk aljabar; 3) siswa mampu memberikan contoh dari suatu konsep, yaitu siswa mampu menentukan contoh lain dari permasalahan aljabar; 4) siswa mampu menyajikan konsep dalam berbagai bentuk representasi matematis, siswa mampu dengan lancar menyajikan konsep dalam berbagai bentuk representasi matematis; 5) siswa mampu mengembangkan syarat perlu atau syarat cukup dari suatu konsep, yaitu siswa mampu menyelesaikan berbagai bentuk permasalahan aljabar yang melibatkan syarat perlu dan syarat cukup namun ada beberapa tahapan yang siswa melakukan kesalahan operasi; 6) siswa mampu menggunakan dan memanfaatkan serta memilih prosedur atau operasi tertentu, yaitu siswa mampu mengoperasikan berbagai bentuk permasalahan aljabar, namun masih ada tahapan yang belum mampu diselesaikan oleh siswa dan 7) siswa mampu mengaplikasikan konsep algoritma pada pemecahan masalah, yaitu siswa mampu menentukan solusi dengan menggunakan konsep aljabar dari permasalahan yang disajikan namun ada beberapa tahapan yang salah dalam menyelesaikan masalah tersebut.

3. Pemahaman konsep matematika siswa yang memiliki kesulitan belajar tinggi.

a. Subjek 5

\section{Gambar 5. Data Hasil Tes Subjek 5}

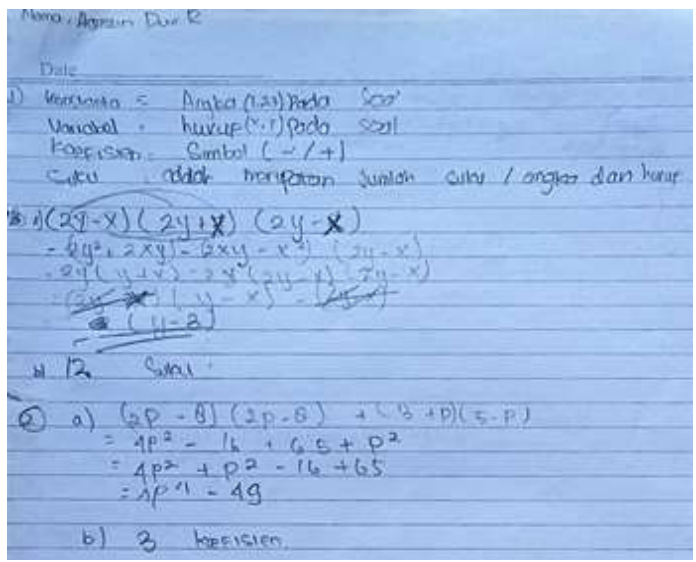


b. Subjek 6

Gambar 6. Data Hasil Tes Subjek 6

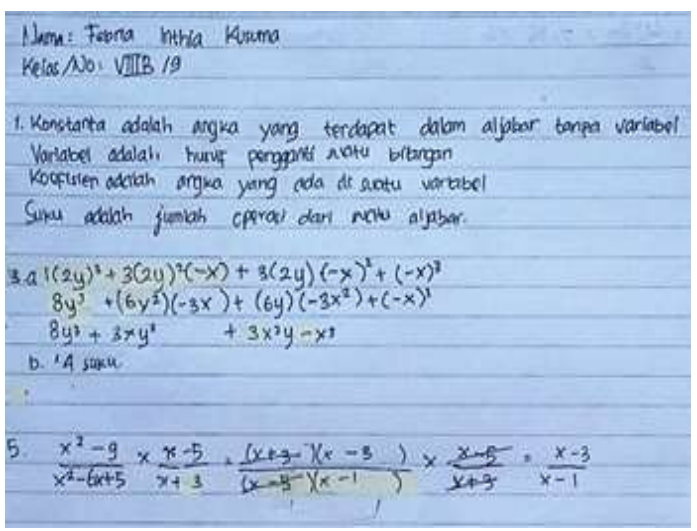

Berdasarkan data yang telah didapat, diperoleh keterangan sebagai berikut : 1) siswa mampu menyatakan ulang sebuah konsep, yaitu telah mampu menyatakan pengertian dari konstanta dan variabel, namun belum mampu menyatakan ulang konsep koefisien, dan suku; 2) siswa mampu mengklasifikasikan objek menurut sifat-sifat tertentu sesuai dengan konsepnya, yaitu siswa telah mampu menentukan variabel dan suku dari suatu bentuk aljabar namun belum mampu menentukan konstanta dan koefisien dari suatu bentuk aljabar; 3) siswa mampu memberikan contoh dari suatu konsep, yaitu siswa mampu menentukan contoh lain dari permasalahan aljabar; 4) siswa belum mampu menyajikan konsep dalam berbagai bentuk representasi matematis, siswa belum mampu menyelesaikan masalah dalam berbagai bentuk representasi matematis, siswa tidak paham akan apa yang dikerjakannya; 5) siswa belum mampu mengembangkan syarat perlu atau syarat cukup dari suatu konsep, yaitu siswa belum mampu menyelesaikan berbagai bentuk permasalahan aljabar yang melibatkan syarat perlu dan syarat cukup, siswa tidak paham akan apa yang dikerjakannya; 6) siswa belum mampu menggunakan dan memanfaatkan serta memilih prosedur atau operasi tertentu, yaitu siswa belum mampu mengoperasikan berbagai bentuk permasalahan aljabar dan 7) siswa belum mampu mengaplikasikan konsep algoritma pada pemecahan masalah, yaitu siswa belum mampu dengan lancar menggunakan konsep faktorisasi suku aljabar pada pemecahan masalah.

Berdasarkan hasil data tersebut diperoleh bahwa subjek pada kategori kesulitan belajar rendah dan sedang mampu memahami konsep lebih banyak dari pada subjek pada kategori bawah. Walaupun subjek pada kelomok kesulitan belajar rendah dan 
Novita Ayu Dewanti, Ponco Sujatmiko, Getut Pramesti/ Phenomenon Vol. 08, No. 1, Juli 2018 sedang memiliki kemampuan yang sama, subjek pada kategori kesulitan belajar rendah mampu memahami konsep lebih dalam dari pada subjek pada kategori bawah. Subjek pada kategori kesulitan belajar tinggi hanya mampu menguasai beberapa konsep aljabar. Hal ini sejalan dengan teori bahwa kemampuan pemahaman matematika siswa sejalan dengan kemampuan dalam menyelesaikan masalah. Siswa yang memiliki kemampuan pemahaman tinggi akan memiliki kemampuan penyelesaian yang tinggi pula. Siswa yang memiliki kemampuan pemahaman rendah akan memiliki kemampuan penyelesaian yang rendah pula. Sedangkan siswa yang memiliki kemampuan pemahaman sedang akan sulit didefinisikan. Hal ini karenan siswa berkemampuan pemahaman sedang akan memiliki kecederungan untuk memiliki kemampuan pemahaman yang tinggi atau memiliki tingkat pemahaman yang rendah Aini, R. N., \& Siswono, T. Y. E. (2014).

\section{SIMPULAN DAN SARAN}

Berdasarkan hasil dan pembahasan maka dapat diperoleh simpulan tentang pemahaman konsep siswa dalam menyelesaikan soal faktorisasi aljabar berdasarkan kesulitan belajar intelektual siswa adalah sebagai berikut :

1. Siswa yang memiliki kesulitan belajar rendah telah mampu menguasai semua indikator pada pemahaman konsep dengan lancar namun ada satu sub-indikator yang belum dikuasai yaitu pada sub-indikator menentukan variabel pada bentuk aljabar yang ditanyakan.

2. Siswa yang memiliki kesulitan belajar sedang telah mampu menguasai semua indikator pada pemahaman konsep walaupun tidak selancar siswa yang memiliki kesulitan belajar rendah namun ada juga sub-indikator yang belum dikuasai yaitu menentukan variabel pada bentuk aljabar yang ditanyakan dan masih terdapat kesalahan pada beberapa tahapan operasi dalam menyelesaikan masalah.

Siswa yang memiliki kesulitan belajar sedang telah hanya mampu menguasai 3 dari 7 indikator pemahaman konsep yang telah ditetapkan yaitu, siswa mampu menyatakan ulang sebuah konsep; mengklasifikasikan objek menurut sifat-sifat tertentu sesuai dengan konsepnya, namun belum mampu menentukan konstanta dan koefisien dari suatu bentuk aljabar; dan memberikan contoh dari suatu konsep. Siswa tidak mampu dalam mengembangkan syarat perlu atau syarat cukup dari suatu konsep, siswa 
Novita Ayu Dewanti, Ponco Sujatmiko, Getut Pramesti/ Phenomenon Vol. 08, No. 1, Juli 2018 tidak paham akan apa yang dikerjakannya; belum mampu menggunakan dan memanfaatkan serta memilih prosedur atau operasi tertentu, yaitu belum mampu mengoperasikan berbagai bentuk permasalahan aljabar dan belum mampu mengaplikasikan konsep algoritma pada pemecahan masalah, yaitu belum lancar menggunakan konsep faktorisasi suku aljabar pada pemecahan masalah.

\section{DAFTAR RUJUKAN}

Abdurrahman, M. (2010). Pendidikan Bagi Anak Berkesulitan Belajar. Jakarta : Rineka Cipta.

Aini, R. N., \& Siswono, T. Y. E. (2014). Analisis Pemahaman Siswa SMP dalam Menyelesaikan Masalah Aljabar Pada PISA. Mathedunesa, 3(2), 159-164.

Dalyono. (1997). Psikologi Pendidikan. Jakarta : Rineka Cipta. http://ejournal.unesa.ac.id/index.php/mathedunesa/issue/archive

Sugiyono. (2014). Memahami Penelitian Kualitatif. Bandung : Alfabeta.

Suryadi, D. (2014). Pendidikan Matematika. Diperoleh pada 21 April 2016, dari http://didi-suryadi.staf.upi.edu/files/2011/06/PENDIDIKAN-MATEMATIKA.pdf.

Widdiharto, R. (2008). Diagnosis Kesulitan Belajar Mateamtika SMP dan Alternatif Proses Remidinya. Yogyakarta : Depdiknas. 